\title{
Transitivity System in CNN Online News
}

\author{
Nurul Qomariah ${ }^{1, *}$ Amrin Saragih ${ }^{2}$ Sri Minda Murni ${ }^{3}$ \\ ${ }^{1}$ English Applied Linguistics Study Program, Postgraduate School Universitas Negeri Medan \\ ${ }^{2}$ English Applied Linguistics Study Program, Postgraduate School Universitas Negeri Medan \\ ${ }^{3}$ English Applied Linguistics Study Program, Postgraduate School Universitas Negeri Medan \\ *Corresponding author. Email: nurqo2111@gmail.com
}

\begin{abstract}
This research aimed at investigating transitivity system elements in CNN Online News. This research was a descriptive qualitative. The data of this research were clauses consist of transitivity system in CNN Online News. The data source was ten of Covid-19 Online News taken from CNN Online News. The data were collected by applying the documentary technique and observation. In doing the analysis, there were some steps of qualitative were used. The steps were data collection, data condensation, data display, and data verification. The findings of the study showed that the types of transitivity system. There were three elements of transitivity systems namely process, participants and circumstances. CNN Online News realized all the types of process: Material process, Mental process, Relational process, Behavioral, Verbal process, and Existential process. Among the process, the dominant was Material Process. CNN Online News realized participants: Actor, Goal, Sayer, Carrier, Attribute, Verbiage, Senser, Phenomenon, Target, Existing, Existence, Behaver, Token, Value, Receiver, Behavior, and Range. The dominant was Actor. CNN Online News realized circumstances: Location, Cause, Manner, Accompaniment, Extent, Matter, Angle, and Role. The dominant was Location. From the findings, we could conclude that in CNN Online News mostly used material process to show the process of doing something physically or involved physical action during covid-19, the actor is obligatory element that represent the 'doer' of the process realized by the clause. The action involved the actor or the person doing something to face coronavirus, the writer of the news focused on the actor to show the efforts made by people involved in the text and the events happened. In CNN mostly used circumstance element of location to show the place and the time when the process or action happened.
\end{abstract}

Keywords: Transitivity system, online news, CNN.

\section{INTRODUCTION}

As a device for communication, language is an effective means of expressing ideas and feelings in both spoken and written forms. Once Individuals speak or write, they produce text. The term 'text' refers to any instance of language [1]. When people produce a text, language is a means of representing and defining real and imaginary events. Transitivity is a fundamental property of language that enables human beings to build a mental picture of reality, to make sense of their experience of what goes on around them and inside them. It is a means of interpreting all the "goings-on"happening, doing, sensing, meaning, and being and becoming around us.

The written text such as News that has the purpose to report facts sometimes is more interested in advancing their own such as taking a certain perspective. News is a serial publication that contains news about some phenomenon. News is a means to convey the idea and perspective of the reader toward a certain phenomenon [2]. In the News, readers can know some phenomenon to convey idea and perspective use language in a certain way. Language in News also can be a source of creating perspective toward the readers and language can be used in many different ways to reinforce and manipulate a message [3]. Hence, like common news articles, news about covid-19 also can be a source of perspective toward the readers especially all societies around the world. He has found that even when the writing is not too biased, the reader may not be aware to accept some writer's perspectives about a fact [4]. Some of the facts are just viewed from a certain point of view which is usually directed to the target readers. Thus, language is not seen as the reflection of our reality anymore and becomes the center of creating reality. 
Online News contains clauses explain about phenomena because that reader needs to know the components of the transitivity system so that meaning of the News clearly understands. The researcher will analyze the components of transitivity system (participants, process, and circumstances) in covid-19 Online News in CNN. Based on the background that has been mentioned before, the problem of this research is to uncover the types of transitivity systems are realized in CNN Online News, the study is focused on the process as an element of Transitivity system specifically consists of material process, mental process, verbal process, relational process, behavioral process, and the last Existential process found in CNN Online News. The News is taken from Cable News Network (CNN) International Edition at edition.cnn.com about Covid-19 which was published in December 2020. So, the objective of this study is uncover the elements of transitivity system in CNN Online News.

\section{REVIEW OF RELATED LITERATURE}

Halliday \& Matthiessen (2014) stated that transitivity refers to a system that construes the world of experience into a manageable set of process types. This system is used to realize the experiential meta function that is one of the sub-function of the ideational meta function in which language is used to express content. Transitivity refers generally to how meaning is represented in the clause. It shows how speakers encode in the language their mental picture of reality and how they account for their experience of the world around them because it is concerned with the transmission of ideas, which is part of the ideational function of language [5]. Transitivity represents a reflection of the processes that take place in the world via formal grammatical components. In transitivity, "grammar is related to reality". It takes into account a paradigmatic conception of language where choices play an essential function. Addressers and addressees do not only compose and decode a spectrum of grammatical constituents but they do so after making choices related to what formal terms they might select to render communication effective.

\subsection{Process}

The process is central to transitivity. Process type is the resource for sorting out our experience of all kinds of events into a small number type. That processing center on that part of the clause that is realized by the verbal group, but it can also be regarded as what "going-on" are represented in the whole clause [6]. Six types of processes can be identified by Halliday \& Matthiessen (2014), namely: (a) Material process, (b) Mental process, (c) Relational, (d) Behavioral, (e) Verbal, and (f) Existential process. The material process is the process of material doing, the mental process is a process involving feeling, thinking, perceiving, and having an emotional reaction to things, the relational process involves states of being (including having), the behavioral process is the process of psychological and psychological behavior, the verbal process is the process of saying, or more accurately, of symbolically signaling, and the existential process is the process of existence.

\subsection{Participants}

Participants represent a thing or people involved in carrying out the process, things, or people affected by the process. Each process in the transitivity system has its key participants, but sometimes there are additional participants. Participants are the person, creature, object, institution, or abstraction that involve in a process (Halliday \& Matthiessen, 2014).

In the material process, there are two participants involved. Participant I is called actor-one of does the deed or the entity who or which does something and participant II is called goal-one that suffers the process or an entity to which the process is extended or directed.

In the mental process, there is a sense as a participant I one need receives, known, like, etc, and phenomenon as participant II that which is received, known, liked, etc. The sense is by definition a conscious being, for only those who are conscious can feel, think, or see.

In the relational process, the identification process has token and value as a participant, and the attribution process has a carrier and attributes as a participant I and II. Processes that establish identity are called identifying processes and processes which assign a quality are called attributive processes.

In behavioral process has one participant called behaver. It is obligatory for participants. In a sense, the behaver is a conscious being. But the process is one of doing, not sensing. In the behavioral process, range names the behavioral enacted.

In the verbal process, there are two participants; sayer and verbiage. The projecting clause encodes a signal source (sayer), signaling (verbal process) and the other (projected clauses) realizes what was said. Three other participants may be incumbent upon the verbal process. They are the ones to whom the verbalization is addressed (receiver), one acted upon verbally (target), and a name for the verbalization itself (range/verbiage).

In the existential process, there is a single participant called existent. Existential processes are expressed by verbs of existing; be, exist, arise and the existent can be a phenomenon of any kind.

\subsection{Circumstances}

Halliday (2014) stated that circumstance is environment nature, location of the process. The 
circumstance is beyond the reach of the process. Types of Circumstantial Element are:

2.3.1 Extent: Circumstantial element of extent answers the question about duration (How long?), frequency (How many times?), and distance (How far?).

2.3.2 Location: Circumstantial element of location answers the question about place (Where?) and time (When?).

2.3.3 Manner: Circumstantial element of Manner answers the question about means (How?), quality (How? and How-ly), comparison (What like?), and degree (How much?).

2.3.4 Cause: Circumstantial element of cause answers the question about Reason (Why?), Purpose (What for?), and behalf (Who for?).

2.3.5 Contingency: Circumstantial element of contingency answers the question about Condition, Default, and Concession (Why?).

2.3.6 Accompaniment: Circumstantial element of accompaniment answers the question about Commutative (Who/what?), and Additive (And who/what else?).

2.3.7 Role: Circumstantial element of role answers the question about Guise (What as?) and Product (What into?).

2.3.8 Matter: Circumstantial element of matter answers the question about matter (What about?).

2.3.9 Angle: Circumstantial element of Angle answers the question about source and point.

\section{RESEARCH METHOD}

This study was conducted by descriptive qualitative research design. This research was intended to uncover the elements of Transitivity system in CNN Online News. The data of this study was clauses consist of transitivity system in CNN about covid-19. The News were taken from Cable News Network (CNN) International Edition at edition.cnn.com about Covid-19 which was published in December 2020.

The data then were analyzed through four steps of qualitative data analysis technique, namely: data condensation, data display, and drawing and verifying conclusions.

\section{DATA ANALYSIS}

The clauses were analyzed to uncover the elements of transitivity system in CNN Online News.

\subsection{Process}

The three process types that occupied mostly in the news, i.e. (1) Material Process (Mat.Pr), (2) Relational Process (Rel.Pr), and Verbal Process (Verb.Pr). The dominant process types realized in CNN Online News was Material Process (Mat.Pr) $216(50,35 \%)$, while the rest, Relational Process (Rel.Pr) 93 (21,68\%), Verbal
Process (Verb.Pr) 82 (19,11\%), Mental Process (Men.Pr) 24 (5,60\%), Behavioral (Beh.Pr) 7 (1,63\%), and Existential (Ext.Pr) 7 (1,63\%). Then, the examples of types processes were used in the clauses of CNN Online News can be seen below:

\subsubsection{Material Process}

Data 1

\begin{tabular}{lll}
\hline Hospitals & stretched & $\begin{array}{l}\text { beyond 'reasonable } \\
\text { limit' }\end{array}$ \\
\hline Actor & Material Process & $\begin{array}{l}\text { Circumstance: } \\
\text { Location }\end{array}$ \\
\hline
\end{tabular}

\subsubsection{Mental Process}

Data 8

\begin{tabular}{lll}
\hline Some patients & are being seen & by doctors \\
\hline Senser & Mental Process & Phenomenon \\
& & \\
\hline
\end{tabular}

\subsubsection{Relational Process}

Data 6

\begin{tabular}{llll}
\hline And & this & was & $\begin{array}{l}\text { the worst of the } \\
\text { pandemic. }\end{array}$ \\
\hline Carrier & $\begin{array}{l}\text { Relational } \\
\text { Process }\end{array}$ & Attribute & \\
\hline
\end{tabular}

\subsubsection{Behavioral Process}

Data 90

\begin{tabular}{lll}
\hline "Our staff & observed & $\begin{array}{l}\text { that staff and } \\
\text { incarcerated persons }\end{array}$ \\
\hline Behaver & Behavioral Process & Behavior \\
\hline
\end{tabular}

\subsubsection{Verbal Process}

\section{Data 3}

One county official told $\mathrm{CNN}$,

in Wisconsin

\begin{tabular}{lll}
\hline Sayer & Verbal process & Verbiage \\
\hline
\end{tabular}

\subsubsection{Existential Process}

\section{Data 158}

\begin{tabular}{llll}
\hline There & is not & $\begin{array}{l}\text { much data } \\
\text { yet }\end{array}$ & $\begin{array}{l}\text { on what happens to } \\
\text { people }\end{array}$ \\
\hline Existing & $\begin{array}{l}\text { Exist } \\
\text { Process }\end{array}$ & Existence & $\begin{array}{l}\text { Circumstance: } \\
\text { Location }\end{array}$ \\
\hline
\end{tabular}

\subsection{Participants}

Participant of Actor and Goal was dominantly realized in the clauses of $\mathrm{CNN}$ Online News, there were $167(26,38 \%)$ of Actor and 141 (22,27\%) of Goal. Actor and Goal are participants in material process. When Actor and Goal were realized dominantly, of course the 
material process was dominantly realized than others. While, Sayer 78 (12,32\%), Carrier 76 (12\%), Verbiage $28(4,42 \%)$, Senser $25(3,95 \%)$, Phenomenon 18 $(2,84 \%)$, Target $6(0,95 \%)$, Existing $6 \quad(0,95 \%)$, Existence $5(0,79 \%)$, Behaver $5(0,79 \%)$, Receiver 3 $(0,47 \%)$, Behavior $2(0,32 \%)$, and Range $1(0,16 \%)$. The examples of types Participants were used in the clauses of CNN Online News can be seen below.

Data 2.

\begin{tabular}{lllll}
\hline And & $\begin{array}{l}\text { doctors } \\
\text { nurses }\end{array}$ & and & across & the US \\
\hline Actor & & Material Process & Goal \\
\hline
\end{tabular}

\section{Data 3}

\begin{tabular}{lll}
\hline $\begin{array}{l}\text { One county official in } \\
\text { Wisconsin }\end{array}$ & told & CNN, \\
\hline Sayer & Verbal process & Verbiage \\
\hline
\end{tabular}

Data 6

\begin{tabular}{llll}
\hline And this & was & $\begin{array}{l}\text { the worst of the } \\
\text { pandemic. }\end{array}$ \\
\hline Carrier & $\begin{array}{l}\text { Relational } \\
\text { Process }\end{array}$ & Attribute \\
\hline
\end{tabular}

Data 45

\begin{tabular}{clllll}
\hline where & Hospitals & $\begin{array}{l}\text { are } \\
\text { feel } \\
\text { ing }\end{array}$ & $\begin{array}{l}\text { the } \\
\text { squee } \\
\text { ze }\end{array}$ & $\begin{array}{l}\text { on } \\
\text { capac } \\
\text { ity }\end{array}$ & $\begin{array}{l}\text { to treat the } \\
\text { incoming } \\
\text { surge of } \\
\text { Covid-19 } \\
\text { patients. }\end{array}$ \\
\hline Senser & $\begin{array}{l}\text { Me } \\
\text { n.Pr }\end{array}$ & $\begin{array}{l}\text { Phen } \\
\text { omen } \\
\text { on }\end{array}$ & $\begin{array}{lll}\text { Circ: } \\
\end{array}$ & $\begin{array}{l}\text { Circ: } \\
\text { Cause }\end{array}$ \\
& & &
\end{tabular}

\subsection{Circumstance}

From the analysis, all circumstantial elements (319 circumstances) were realized in CNN Online News with various numbers. Circumstance Location dominated in use in CNN Online News, the number of circumstantial elements: Circumstance: Location (Circ.L) 193 (60,50\%), Circumstance: Cause (Circ.Cause) $50 \quad(15,67 \%)$, Circumstance: Manner (Circ.Man) 22 (6,90\%), Circumstance: Accompaniment (Circ.Acc) 21(6,58\%), Circ: Extent 10 (Circ.Ext) (3,13\%), Circumstance: Matter (Circ.Mat) $10 \quad(3,13 \%)$ Circumstance: Angle (Circ.Angle) 10 (3,13\%), and the last Circumstance: Role $3(0,94 \%)$. The examples of types circumstances were used in the clauses of CNN Online News can be seen below:

\section{Data 5}

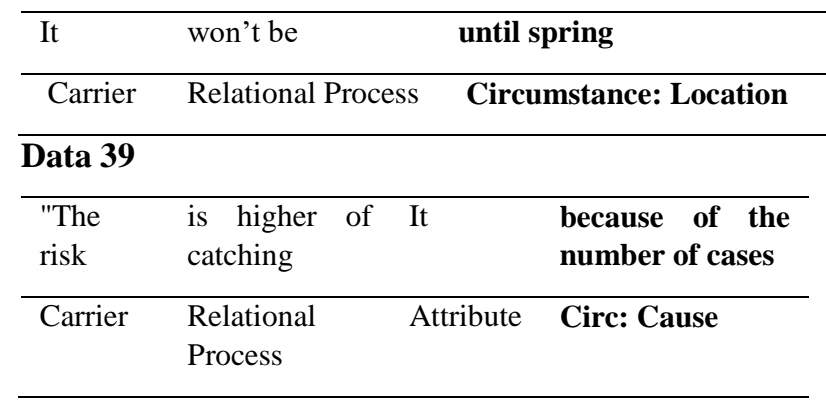

\section{Data 23}

\begin{tabular}{llll}
\hline $\begin{array}{l}\text { the vaccines' } \\
\text { first } \\
\text { shipments }\end{array}$ & $\begin{array}{l}\text { could } \\
\text { happen }\end{array}$ & $\begin{array}{l}\text { December } \\
15 \text { and 22, }\end{array}$ & respectively, \\
\hline Actor & $\begin{array}{l}\text { Material } \\
\text { Process }\end{array}$ & Goal & Circ: Manner \\
& & & \\
\hline
\end{tabular}

\section{Data 116}

\begin{tabular}{llll}
\hline We & $\begin{array}{l}\text { must really } \\
\text { not become }\end{array}$ & comfortable & $\begin{array}{l}\text { with the fact that } \\
\text { over 70\% of } \\
\text { African } \\
\text { Americans }\end{array}$ \\
& & & \\
\hline Actor & Material & Goal & Circ: \\
& Process & & Accompaniment \\
\end{tabular}

Data 28

\begin{tabular}{lllll}
\hline CDC & continues & $\begin{array}{l}\text { to } \\
\text { recommen } \\
\text { d } \\
\text { quarantini } \\
\text { ng }\end{array}$ & $\begin{array}{l}\text { for } \mathbf{1 4} \\
\text { days as } \\
\text { the best } \\
\text { way }\end{array}$ & $\begin{array}{l}\text { to reduce } \\
\text { the risk of } \\
\text { spreading } \\
\text { Covid-19, }\end{array}$ \\
& & Goal & Circ: & Circ: \\
Actor & $\begin{array}{l}\text { Material } \\
\text { Process }\end{array}$ & & Extent & Cause \\
& & & &
\end{tabular}

\section{FINDINGS}

Based on the data analysis conducted, it was found that CNN Online News realized all the types of process: Material process, Mental process, Relational process, Behavioral, Verbal process, and Existential process. Meanwhile, there were six types of process realized in CNN Online News. Among the process, the dominant was Material Process. CNN Online News realized participants: Actor, Goal, Sayer, Carrier, Attribute, Verbiage, Senser, Phenomenon, Target, Existing, Existence, Behaver, Token, Value, Receiver, Behavior, and Range. There were seventeen participants realized in CNN Online News. The dominant was Actor. CNN Online News realized circumstances: Location, Cause, Manner, Accompaniment, Extent, Matter, Angle, and Role. The dominant was location. From the findings, we could conclude that in CNN Online News mostly used 
material process to show the process of doing something physically or involved physical action during covid-19, the actor is obligatory element that represent the 'doer' of the process realized by the clause. The action involved the actor or the person doing something to face coronavirus, the writer of the news focused on the actor to show the efforts made by people involved in the text and the events happened. In CNN mostly used circumstance element of location to show the place and the time when the process or action happened.

\section{ACKNOWLEDGMENTS}

The writers would like to express their highest gratitude and appreciation to families, friends, and lecturers, who have been very helpful, kind, patient in giving advice, ideas, guidance, assistance, and their valuable time during the process of writing and conducting the study.

\section{REFERENCES}

[1] Halliday, M.A.K., and Matthiessen, C.M. 2014. Halliday's Introduction to Functional Grammar (4th ed). London: Arnold.

[2] Suparto, A.D. (2018). Transitivity Analysis on Framing in the Online News Articles. Ranah: Journal Kajian Bahasa.

[3] Ghannam, D. (2011). Newspaper Ideology: A Critical Discourse Analysis of an event Published in six Lebanese Newspapers. Johannesburg: University of the Witwatersrand

[4] Mineshima, M. (2009). Discourse Analysis of News Texts by the application of Systemic Functional Grammar. Niagata Institute of Technology. Pp. 101-123.

[5] Simpson, Paul. 1993. Ideology and Point of View. London: Routledge

[6] Bloor, T and Bloor, M. 2013. The Functional Analysis of English. A Hallidayan Approach. (3rd ed). New York: Oxford University Press. 